\title{
SISTEM RELIGI MASYARAKAT JAWA \\ DALAM NOVEL MANTRA PEJINAK ULAR KARYA KUNTUWIJOYO (KAJIAN ANTROPOLOGI SASTRA)
}

\author{
Jafar Lantowa, Zilfa A. Bagtayan \\ Universitas Negeri Gorontalo \\ jafar_lantowa@yahoo.com,butterfly_blackwhite@yahoo.com
}

\begin{abstract}
ABSTRAK
Penelitian ini bertujuan untuk mendeskripsikan sistem religi masyarakat Jawa melalui novel Mantra Pejinak Ular karya Kuntowijoyo. Pendekatan yang digunakan adalah pendekatan antropologi sastra. Dalam menganalisis unsur budaya khususnya sistem religi masyarakat Jawa dalam novel, maka peneliti menggunakan metode deskriptif interpretatif yakni memanfaatkan cara-cara penafsiran dengan menyajikannya dalam bentuk deskripsi. Pengumpulan data dilakukan dengan teknik baca dan catat, kemudian dianalisis dengan menggunakan pendekatan antropologi sastra dengan model analisis konten. Analisis konten dilakukan melalui tahap inferensi, analisis, validitas dan reliabilitas. Hasil penelitian menunjukkan bahwa sistem religi masyarakat Jawa terdiri atas Islam kejawen dan Islam santri. Islam kejawen tampak pada kepercayaan terhadap makam leluhur sebagai sumber keberkahan, upacara selamatan, sesajen, makhluk halus, kesakten, pohon keramat, yang dianggap mendatangkan keselamatan, kebahagiaan, namun juga bisa menimbulkan gangguan pikiran. Islam santri tergambar melalui tokoh Haji Syamsudin yang menjalankan syariat ajaran Islam dan membersihkan akidahnya dari perilaku syirik serta menasehati Abu Kasan Sapari untuk memutuskan diri dari mata rantai kesyirikan.
\end{abstract}

\begin{abstract}
This study aims at describing the religious belief system of Javanese community through Mantra Pejinak Ular novel written by Kuntowijoyo. In analyzing the cultural elements particularly the religious belief system of the Javanese community, the researchers utilized interpretative description by describing and presenting the analysis of the data. Data collection was obtained through reading and note taking, and then the data wasanalyzed by using the literary anthropology approach through content analysis. The results revealed that religious belief system of the Javanese community comprises of kejawen Islam and santri Islam. Kejawen Islam is evident from the way the community believes in the ancestral graves as the source of blessing, protection rituals, offerings, the spirits, kesakten, sacred trees, which are considered to bring protection and wellbeing, happiness and yet also create mental disorder to individuals. Santri Islam, on the other hand, is depicted in the figure of Haji Syamsudin who followed the Islamic teaching and law and cleaned his belief and shirk behavior as well as advised Abu Kasan Sapari to stay away from any shirk-doings.

Keywords: religious belief system, Javanese community, literary anthropology, novel
\end{abstract}




\section{PENDAHULUAN}

Sastra Indonesia berwarna lokal disebut Budi Darma sebagai "sastra subkebudayaan".

Sastra sub-kebudayaan muncul sebagai perwujudan dari kerinduan pengarang untuk lepas dari aspirasi global. Di satu pihak, kita menjadi manusia nasional dan internasional, namun di lain pihak kita menuntut untuk kembali ke masa kanakkanak kita sendiri, ke kebudayaan kita sendiri. Menurut Budi Darma, Sastra Indonesia yang menyuarakan kerinduan untuk kembali ke sub-sub kebudayaan masing-masing justru semakin memperkuat kedudukan sastra Indonesia (dalam Yohanes, 2015:390-391). Abrams (1971:89) mengemukakan bahwa sastra warna lokal adalah sastra berlatar belakang daerah, berupa adat istiadat, kebiasaankebiasaan, dialek, cara berpikir, dan perasaan masyarakat". Sastra warna lokal memiliki unsur-unsur kebudayaan yang akan menampilkan ciri khas kedaerahan atau lokalitas yang ditampilkan dalam karya sastra.

Dalam menganalisis unsur kebudayaan dalam sastra, Koentjaraningrat (2000: 80) membatasi unsur kebudayaan menjadi tujuh bagian yaitu sistem bahasa, sistem pengetahuan, sistem kekerabatan dan organisasi sosial, sistem peralatan hidup dan teknologi, sistem mata pencaharian hidup, sistem religi, kesenian. Dari ketujuh unsur tersebut, sistem religi menjadi pembahasan menarik dalam menampilkan warna lokal masyarakat Jawa yang terkenal dengan Islam kejawen dan Islam Santri khususnya dalam novel Mantra Pejinak Ular karya Kuntowijoyo. Sistem keyakinan dan keagamaan menurut Koentjaraningrat dapat berwujud pada pikiran manusia, yang menyangkut keyakinan dan konsepsi manusia tentang sifat Tuhan, tentang wujud alam gaib, tentang terjadinya alam dan dunia, tentang zaman akhirat, tentang wujud dan ciri kekuatan sakti, roh nenek moyang, roh alam, dewa-dewa, roh jahat, hantu, dan makhluk halus lainnya. Kecuali dari itu, sistem keyakinan juga menyangkut sistem nilai dari sistem keagamaan, ajaran kesusilaan, dan ajaran religi lainnya yang mengatur tingkah laku manusia.

Novel Mantra Pejinak Ular merupakan salah satu novel yang dikategorikan sebagai sastra warna lokal karena menampilkan berbagai unsur budaya Jawa terutama sistem religi atau kepercayaan masyarakat Islam Kejawen yang percaya kepada kesakten, mitos dan makhluk halus serta ditampilkan melalui berbagai upacara ritual. Orang jawa mempunyai tradisi kepercayaan terhadap kekuatan magis, kekuatan di luar fisiknya. Orang Jawa takut kepada kekuatan di luar kekuasaannya, dan menghormati hal-hal yang bersifat religious. Rasa takut dan hormat ini menyebabkan orang Jawa sering menggunakan bahasa dan tindakan simbolis dalam berbagai kepentingan (Herusatoto, 2000: 77-78). Selain itu, ditampilkan juga Islam Jawa Santri yang taat terhadap keyakinan ajaran Islam dan menolak berbagai tradisi yang tidak sesuai dengan ajaran Islam.

Dalam setting budaya Jawa, warna Islam selalu mewarnai karya-karya Kuntowijoyo. Melalui tokoh utama yakni Abu Kasan Sapari, Kunto berusaha menyadarkan masyarakat di sekitarnya untuk terlepas dari kepercayaan mitos dan kembali kepada kemurnian ajaran Islam. Menurut Anwar (2005: 29) persoalan manusia dan kehidupan masyarakat modern ditampilkan Kuntowijoyo dalam atmosfer budaya Jawa dan pemikiran Islam. Hantu, takhayul, jin, peri, firasat, 
kepercayaan orang-orang Jawa yang irasional dan emosional dihayati Kuntowijoyo dalam perspektif Islam. Ia menghadapkan dua wawasan tersebut, tanpa membenturkannya. Hal tersebut terungkap melalui novel Mantra Pejinak Ular yang direpresentasikan melalui tokoh Abu dalam menghadapi dua benturan aliran kepercayaan yakni kepercayaan Islam kejawen dan Islam santri yang sudah berkembang dalam masyarakat Jawa.

Dalam mengungkap sistem religi masyarakat Jawa tersebut, peneliti menggunakan pendekatan antropologi sastra dengan memanfaatkan teori representasi budaya melalui konsep Koentjoroningrat mengenai unsur-unsur budaya terutama terkait dengan sistem religi sebagai warna lokal dalam sastra Indonesia mutakhir. Antropologi sastra adalah analisis dan pemahaman terhadap karya sastra dalam kaitannya dengan kebudayaan. Karya sastra bukan refleksi, bukan semata-mata memantulkan kenyataan, melainkan merefraksikan, membelokkannya sehingga berhasil mengevokasi keberagaman budaya secara lebih bermakna. Aspek antropologis meliputi keseluruhan karya sekaligus menunjukkan bahwa antropologi sastra merupakan model pendekatan yang sangat penting. Analisis antropologis adalah usaha untuk mencoba memberikan identitas terhadap karya tersebut, dengan menganggapnya sebagai mengandung aspek tertentu, dalam hubungan ini ciri-ciri kebudayaannya. Ciri-cirinya, di antaranya: memiliki kecenderungan ke masa lampau, citra primordial, citra arketipe. Ciri-ciri yang lain misalnya mengandung aspek-aspek kearifan lokal dengan fungsi dan kedudukannya masing-masing, berbicara mengenai suku-suku bangsa dengan subkategorinya, seperti; trah, klen, dan kasta (Ratna, 2011:31,39-40). Antropologi sastra dalam pandangan Poyatos adalah ilmu yang mempelajari sastra berdasarkan penelitian antarbudaya. Penelitian budaya dalam sastra tentu diyakini sebagai refleksi kehidupan (Endraswara, 2015: 3-4).

Aspek-aspek antropologis dalam karya sastra, meliputi sistem pengetahuan, adat-istiadat, sistem kekerabatan, sistem peralatan hidup dan teknologi, mata pencaharian, kesenian, serta sistem kepercayaan dan agama (Sudikan, 2007: 6). Menurut Koentjaraningrat kajian antropologi dalam memahami unsur religi sebagai kebudayaan manusia tidak dapat dipisahkan dari religious emotion atau emosi keagamaan. Emosi keagamaan adalah perasaan dalam diri manusia yang mendorongnya melakukan tindakan-tindakan yang bersifat religius. Emosi keagamaan ini pula yang memunculkan konsepsi bendabenda yang dianggap sakral dan profan dalam kehidupan manusia Dalam sistem religi terdapat tiga unsur yang harus dipahami selain emosi keagamaan, yakni sistem keyakinan, sistem upacara keagamaan, dan umat yang menganut religi itu. Secara evolusionistik, religi manusia juga berkembang dari bentuk yang sederhana ke bentuk yang kompleks. Perhatian utama para ahli antropologi pada awalnya adalah mengenai bentuk religi atau keyakinan yang bersifat alami. Misalnya, kepercayaan menyembah pada suatu kekuatan gaib di luar diri manusia, berupa gunung, angin, hutan, dan laut. Kepercayaan tersebut berkembang pada tingkatan yang lebih tinggi, yakni kepercayaan kepada satu dewa saja (monotheism) dan lahirnya konsepsi agama wahyu, seperti Islam, Hindu, Buddha, dan Kristen. Sistem religi juga mencakup mengenai dongeng-dongeng atau cerita yang dianggap suci mengenai sejarah para dewa-dewa (mitologi). 
Dalam pendekatan antropologi sastra terdapat teori representasi budaya sebagai alat dalam mengungkap cerminan budaya dalam sastra. Representasi adalah gambaran apa saja yang ada dalam sastra. Gambaran dapat disebut citra. Sastra akan mencitrakan kehidupan manusia. Peneliti antropologi sastra adalah orang yang membawa teropong untuk melihat apa yang ada dalam sastra dan apa yang ada dibalik realitas teks. Teks sastra biasanya menyembunyikan makna. Derajat persembunyian makna itulah yang apabila terungkap akan mereprsentasikan makna. Jadi, representasi adalah pemaknaan atas dasar fenomena teks. Representasi adalah pencerminan yang dapat menangkap segala hal tentang aspek budaya dalam sastra (Endraswara, 2015: 28). Representasi adalah pencerminan yang dapat menangkap segala hal tentang aspek budaya dalam sastra. Cavallaro menyatakan bahwa representasi sejajar dengan citra. Penelitian antropologi sastra dapat mengungkap pencitraan budaya dalam sastra. Persoalan citra tokoh perempuan, buruh, budaya priayi, citra petani, dan lain-lain dapat menjadi fokus penelitian. Beberapa hal yang diungkap dalam representasi antara lain (a) penampilan dramatis tokoh lewat dialog-dialog, deskripsi sastrawan; (b) fakta-fakta setting tradisi, tempat ibadah; (c) fenomena alam, sosial, interaksi multikultural, dan sebagainya. Dengan demikian, peneliti antropologi sastra perlu memilih sastra yang baik, yaitu karya yang merepresentasikan aneka budaya secara lengkap yaitu seluruh proses dan karya serta tindakan manusia (Endraswara, 2015: 28-29). Tujuan penelitian ini adalah mendeskripsikan sistem religi masyarakat Jawa dalam novel Mantra Pejinak Ular karya Kuntowijoyo.

\section{METODE PENELITIAN}

Dalam mengungkap representasi budaya terkait dengan sistem religi masyarakat Jawa dalam Novel Mantra Pejinak Ular karya Kuntowijoyo, peneliti menggunakan metode deskriptif interpretatif. Metode ini digunakan dengan cara memanfaatkan cara-cara penafsiran dengan menyajikannya dalam bentuk deskripsi. Pendekatan yang digunakan dalam penelitian ini adalah pendekatan antropologi sastra dengan memfokuskan pada penelitian teks sastra yang meneliti refleksi sastra sebagai pantulan budaya. Teknik pengumpulan data dilakukan dengan teknik baca dan catat. Novel Mantra Pejinak Ular dibaca secara cermat, teliti, dan berulang-ulang untuk menemukan sistem religi yang terkandung di dalamnya baik yang implisit maupun eksplisit. Data yang telah ditemukan dianalisis menggunakan pendekatan antropologi sastra dengan model analisis konten. Analisis konten dilakukan melalui tahap inferensi, analisis, validitas dan reliabilitas. Inferensi bertumpu pada makna simbolik melalui pengkodean dengan berdasar pada teori representasi dan dianalisis dengan metode hermeneutik. Selanjutnya dilakukan validitas semantik dengan mengukur tingkat pemahaman makna dan reliabilitas yang dipakai adalah keakuratan, yakni penyesuaian hasil penelitian dengan kajian pustaka dan reliabilitas interrater (antartim peneliti).

\section{HASIL DAN PEMBAHASAN}

Agama Islam umumnya berkembang baik di kalangan masyarakat orang Jawa. Hal ini tampak nyata pada bangunan-bangunan khusus untuk tempat beribadat orang-orang beragama Islam. Walaupun demikian tidak semua orang beribadat menurut agama Islam, sehingga berlandaskan atas kriteria pemeluk 
agamanya, ada yang disebut Islam santri dan Islam kejawen. Orang santri adalah penganut agama Islam di Jawa yang secara penuh dan teratur menjalankan ajaranajaran dan agamanya. Adapaun golongan orang Islam kejawen, walaupun tidak menjalankan salat, atau puasa, serta tidak bercita-cita naik haji, tetapi toh percaya kepada ajaran keimanan agama Islam. Orang Jawa percaya kepada sesuatu kekuatan yang melebihi segala kekuatan di mana saja yang pernah dikenal, yaitu kasakten, kemudian arwah atau ruh leluhur, dan makhluk-makhluk halus seperti misalnya memedi, lelembut, tuyul, demit, serta jin dan lainnya yang menempati alam sekitar tempat tinggal mereka. Menurut kepercayaan mereka masing-masing makhluk halus tersebut dapat mendatangkan sukses-sukses, kebahagiaan, kententeraman, ataupun keselamatan, tetapi sebaliknya bisa pula menimbulkan gangguan pikiran, kesehatan, bahkan kematian. Maka bilamana seseorang ingin hidup tanpa menderita gangguan itu, ia harus berbuat sesuatu untuk mempengaruhi alam semesta dengan misalnya berprihatin, berpuasa, berpantang melakukan perbuatan serta makan tertentu, berselamatan, dan bersaji. Kedua cara terakhir ini kerap kali dijalankan oleh masyarakat orang Jawa di desa-desa di waktu yang tertentu dalam peristiwa-peristiwa kehidupan sehari-hari (Kodiran, 2010: 346-347). Menurut Santosa (2012:197), "Kejawen adalah pandangan hidup (filsafat) yang mengutamakan dimensi kerohanian, kejiwaan, batin, mental, moral, jiwa, roh, yang bersumber pada nilai-nilai khas Jawa."

Dalam novel Mantra Pejinak Ular karya Kuntowijoyo menampilkan berbagai sistem religi terutama gambaran golongan Islam kejawen. Novel ini mengisahkan seorang tokoh utama yakni Abu Kasan Sapari yang berada pada lingkungan tradisi Islam kejawen sehingga terpengaruh pada pola asuh kedua orang tua dan kakeknya. Kakek Abu dari pihak ayah adalah seorang Islam kejawen yang memiliki kepercayaan terhadap makam leluhur sebagai sumber memperoleh keberkahan dan keselamatan hidup. Kakek tersebut membawa bayi ke makam Ronggowarsito untuk memohon doa restu dalam memperoleh keberkahan dalam hidup bayi tersebut, seperti tampak pada data berikut.

Kemudian, Kakek meminta bayi itu. Dibawanya bayi merah yang terbungkus kain batik ke kuburan Ronggowarsito untuk ngalap berkah, meminta restu. Sambil meyerahkan kembali bayi itu dikatakannya kepada dua orangtuanya, "Hati-hati memelihara anak ini. Besok dia akan jadi pujangga. Aku mendapat firasat, ketika aku keluar dari makam ada rombongan orang membarang, menyanyi, dan menabuh gamelan. Anak itu memiringkan telinganya, seperti mendengar sinden dan kelenengan." (Kuntowijoyo, 2013:2).

Data tersebut menampilkan keyakinan masyarakat Jawa dalam memanjatkan doa kepada Sang Pencipta dengan mengunjungi makam leluhur yang merepresentasikan bentuk penghormatan masyarakat Jawa terhadap para leluhurnya, apalagi kepada makam leluhur sebagai seorang pujangga yang sangat dihargai dan dimuliakan oleh masyarakat Jawa sebagai sumber memperoleh keberkahan.

Dalam novel ini juga digambarkan sistem religi masyarakat Jawa melalui kelahiran anak dengan melaksanakan upacara selamatan. Selamatan adalah suatu 
upacara pokok atau unsur terpenting dari hampir semua ritus atau upacara dalam sistem religi orang Jawa pada umumnya (Koentjaraningrat, 1994:344). Sistem religi berupa upacara kelahiran bayi melalui upacara selamatan hari kelima yang disebut orang Jawa sebagai sepasaran dengan melaksanakan syukuran atau kenduri.

Pada hari kelima diadakan sepasaran dengan mengundang macapatan dan gamelan sederhana. Dengan bangga kakek itu mengumumkan bahwa cucunya diberi nama Abu Kasan Sapari. Abu diambil dari nama sahabat Nabi Abu Bakar, Kasan adalah nama cucu nabi, dan Sapar adalah bulan perkaeinan kedua orangtuanya. Diharapkannya bahwa nama itu ada pengaruhnya pada jabang bayi yang baru lahir. Kemudian dengan suara serak seseorang tua melagukan Dandanggula, peninggalan Sunan Kalijaga yang bersisi doa keselamatan...

Pembacaan macapat itu ditutup dengan kenduri dan doa yang dipimpin oleh modin desa. Kakek itu adalah juru kunci makam Ronggowarsito di Desa Palar, Klaten. (Kuntowijoyo, 2013:3-4).

Upacara selamatan ini menjadi tradisi masyarakat Jawa terutama tergambar melalui kakek Abu Kasan dari pihak ayah Abu yang memaknai bahwa doa selamatan ini sebagai bentuk syukur kepada Tuhan dan bermohon perlindungan agar sang Bayi bisa hidup tentram dan jauh dari penyakit. Nama pemberian kakek yakni Abu Kasan Sapari mencerminkan sistem religi yang dianut oleh kakeknya yakni keyakinan terhadap ajaran Islam dengan mengacu kepada nama sahabat nabi, cucu nabi, dan bulan Hijriyah. Namun, dibalik keyakinannya terhadap ajaran Islam, kakek juga memiliki keyakinan terhadap bulan yang mendatangkan keberkahan si bayi.

Pagi sekali ketika cucu laki-laki itu agak agal dijemputnya, dan seperti mainan, akan dibopongnyajalan-jalan sambil dinyanyikannya, "Lir-ilir lirlir tandure wus sumilir, ijo royo-royo tak sengguh temanten anyar." (Tanaman sudah tumbuh, hijau sekali saya kira temanten baru). Pada sore terang bulan kakek itu akan membawanya ke tepi sawah, sebab di tempat itu bulan tidak terhalang pohon-pohon dan rumah-rumah. Sambil mengharap berkah bulan ia akan berkata, "Run-turun. Bulan, minta kuningmu. Bulan, minta cahayamu."

Keyakinan terhadap bulan sebagai sumber keberkahan mengakar pada diri kakek yang terpengaruh pada unsur percampuran kepercayaan sekaligus yakni Islam-Hindu-Budha yang disebut sebagai sinkritisme terutama pada masyarakat Islam kejawen. sinkritisme merujuk pada kepercayaan masyarakat Jawa yang menggabungkan ajaran Islam dengan kejawen, yakni kepercayaan terhadap makhluk halus, roh leluhur, dan benda-benda langit.

Sistem religi lainnya juga tampak pada acara aqiqah yang dilaksanakan oleh kakek-nenek Abu Kasan dari pihak Ibu yang mengarah kepada ajaran Islam dalam melaksanakan aqiqah bagi bayi yang dilahirkan.

Sesampai di desa baru, kakek-nenek tahu bahwa kelahiran Abu belum disambut dengan akikah. Maka, dipotonglah dua ekor kambing jawa. Betul 
kambing begituan lebih berbau, tapi dagingnya lebih enak.. Anak-anak aan bermain teka-teki, "Ada kambing menari di atas sendok, apa?" Jawabnya: gulai kambing! Kambing-kambing dimasak, dan malam hari diundang kelompok shalawat, "Shalu'alaih!'. Kemudian rebana dbunyikan oleh beberapa orang yang memegang rebana dengan tangan kiri dan memukulnya dengan tangan kanan. Riwayat Nabi dari buku Barzanji dinyanyikan bersama-sama, "Ya Nabi, salamun 'alaik. Ya Rasul, salamun "alaik. Ya habibi, salamun alaik." ("Wahai Nabi, sejahtera bagimu. Wahai Utusan, sejahtera bagimu. Wahai kekasih, sejahtera bagimu") (Kuntowijoyo, 2013:7).

Dalam ajaran Islam, setiap bayi yang lahir dianjurkan untuk melaksanakan aqiqah. Aqiqah ini menjadi bentuk keyakinan orang Islam dalam ritual bagi bayi yang baru lahir sebagai bentuk syukur terhadap Tuhan. Dalam sistem religi, pelaksanaan aqiqah termasuk upacara ritual yang diyakini oleh penganut Islam sebagai bentuk syukur dengan berkorban hewan kambing berupa kambing dua ekor bagi anak laki-laki dan satu ekor bagi anak perempuan. Ritual Aqiqah ini bertujuan untuk mendoakan keselamatan dan kesalehan si bayi. Melalui data tersebut tergambar sistem religi Islam yang diyakini oleh masyarakat Jawa melalui ritual aqiqah si bayi laki-laki yang ditandai dengan berkorban dua ekor kambing. Kakek dan nenek Abu ini sebagai keluarga priyai, sehingga Abu diperlakukan dengan tradisi keluarga priyai dengan mengharapkan Abu akan menjadi priyai yang dapat menguasai dan melestarikan budaya Jawa khusunya pewayangan dan dalang.

"Neneknya melarang dia ke sungai, dan memanjat pohon tinggi, "Kau harus jadi priayi, maka jangan bertingkah seperti petani,"katanya."

"Kami tidak bisa memberimu kekayaan, tapi tuntutlah ilmu. Kata Nabi, tuntutlah ilmu walaupun sampai negeri China. Ilmu itu di aku tidak kentara, dibuang tidak bersuara. "Karena itu, selain sekolah SD, Abu masih harus ke sekolah Diniyah, dan mengaji di surau. Dan selepas Isya, waktu terang bulan, anak-anak lain masih bermain-main, kakeknya akan menyuruhnya pulang, meskipun ia sedang main sembunyi-sembunyian di pematang dekat surau. "Calon Priayi tidak boleh begadang," katanya.

"Pada hari Minggu pagi, waktu anak-anak lain main bola, Abu akan diantar kakeknya ke dalang Notocarito (nama sebenarnya adalah Bakuh), kawannya di sekolah Jawa (Sekolah Angka Loro) dan mengaji di masjid dahulu yang mempunyai seperangkat gamelan dan satu set wayang. Selain menjadi dalang, dia juga bekerja sebagai pegawai kesenian-sungguh seorang priyai tulen menurut gambaran kakek itu. Di sana AB kecil belajar apa saja (istilahnya nyantrik): membersihkan gamelan, menggotong gamelan, melihat orang belajar dalang, melihat orang menata wayang, mendengarkan gamelan ditabuh. Di tempat itu sepertinya kekerasan hati kakeknya luluh lantak oleh bunyi gamelan. (Kuntowijoyo, 2013:12).

Data tersebut menggambarkan sistem religi Jawa yang berlandaskan pada wayang sebagai sumber spiritualitas. Kakek nenek Abu dari pihak ibu sebagai 
keluarga priayi memiliki harapan yang besar kepada Abu sebagai cucu mereka untuk menjadi priyai sehingga semua aktivitas Abu diawasi. Dalam mewujudkan keinginan mereka, akhirnya Abu dimasukan ke sekolah untuk belajar menjadi dalang sambil nyatrik menuntut ilmu agama demi masa depan Abu. Seni Pewayangan memiliki nilai spritualitas yang tinggi dalam memanusiakan manusia. Seni Wayang memiliki hubungan antara olah jiwa masyarakat Jawa dan keyakinan terhadap Sang Pencipta, sehingga melalui seni pesan-pesan moral dapat tersampaikan dan menyentuh hati nurani masyarakat Jawa. Seni Wayang menjadi sumber dakwah bagi masyarakat priyai dalam neningkatkan nilai-nilai moralitas dan kebijaksanaan hidup. Oleh karena itu, Abu Kasan dipersiapkan untuk menjadi dalang dalan meneruskan tradisi pewayangan sebagai alat dalam berdakwah. Dalam lakon-lakon yang ditampilkan dalam perwayangan biasanya menyimpan beberapa nilai, seperti pendidikan, kebudayaan dan ajararan-ajaran dari filsafat Jawa dan Sunda. Menurut Kuntowijoyo keterkaitan antara seni dan agama terletak pada adanya nilai estetis dalam agama dan hadirnya unsur-unsur moralitas agama dalam seni. Di Jawa, wayang kulit memliki spiritualistas Islam yang bertemu secara simbolis dengan budaya Kejawen, sehingga keislaman yang diekspresikan masuk ke dalam kebudayan Jawa, melahirkan spiritualitas keislaman yang heterodok. Hal ini ditujukkan tidak hanya dari model-model wayang serta pemahaman narasi wayang yang masih mempertahankan keaslian budaya Jawa masa lalu yang kuat, tetapi juga filosofi spiritualitas wayang itu sendiri yang berfungsi awal sebagai sarana pemujaan roh-roh leluhur pada masa lalu yang bersifat mistik-animistik (Masroer, 2015). Seni Wayang ini ditampilkan dalam novel melalui Abu Kasapari sebagai orang yang diharapkan untuk meneruskan tradisi pewayangan karena kepercayaan Islam-Kejawen yang dianutnya. Seni Wayang ini menjadi bagian dari sistem religi masyarakat Jawa, karena di dalamnya mengandung nilai spritualitas berupa penyatuan diri dengan Tuhan dan makhluk gaib yang menyatu dengan budaya Islam Kejawen masyarakat Jawa. Tokoh Aku sebagai perwakilan penerus tradisi Islam Kejawen melalui Eyang yang begitu dihargai tampak melalui kutipan berikut.

Ia berketetapan menjadi dalang, menjadi penerus tradisi Eyang dan tradisi Ronggowarsito menghibur dan mengajarkan kebijaksanaan hidup ((Kuntowijoyo, 2013:271).

Kutipan novel tersebut menjadi akhir dari cerita novel yang menggambarkan pada prinsip Abu sebagai keturunan dari Ronggowarsito dalam mempertahankan profesinya sebagai dalang untuk mengajarkan kebijaksanaan hidup. Profesi tersebut sangat berharga bagi Abu, karena dunia pewayangan memiliki nilai spritualitas yang menjadi bagian dalam Islam Kejawenya yang harus dipertahankan.

Dalam sistem religi juga tampak pada keyakinan terhadap mantra yang dititipkan seorang misterius atau makhluk halus kepada Abu Kasan setelah Abu beranjak dewasa. Mantra ini merupakan mitos yang ditampilkan oleh Kuntowijoyo melalui Abu Kasan. yang tepat."

"Kau tidak boleh meninggal sebelum mengajarkan ilmu ini pda orang 
"Apa itu?"

"Mantra Pejinak Ular."

Kemudian orang itu mencari telinga kanan $\mathrm{Abu}$, dan membisikkan sebuah kalimat.

"Paham?"

Kemudian orang itu kembali berbisik di telinga kanan Abu.

"Sudah, ya?" Abu mngangguk. "Mantra itu tidak boleh salah ucap. Bacalah itu setiap kali kau menghadapi ular."

"Mantranya kok bahasa Arab, ya?"

"Ya, ini semua dari Al Quran. Kita orang Jawa itu yang jadi jawabnya, pernyataannya. Pada zaman dulu, ada banjir bandang di Negeri Kanjeng Nabi Nuh. Kanjeng Nabi Nuh yang sudah menyiapkan kapal, naik kapal bersama orang-orang beriman, dan binatang sepasang-sepasang. Termasuk sepasang ular yang kemudian menurunkan ular-ular di seluruh dunia. Mantra itu menandakan bahwa kita adalah anak-cucu Kanjeng Nabi Nuh." Abu mencoba mengingat kalimat itu lagi, dan melapalkannya pelan-pelan. "Bagus, itu sudah betul. Ada laku yang harus dijalankan dan wewaler, Pantangan yang tak boleh dilanggar. Laku-nya dalah kau harus ngebleng tidak makan-minum selama tiga hari, kemudian mutih tidak makan garam selama tujuh hari. Wewaler-nya mudah, tapi sulit dijalankan. Kau tidak boleh melangkahi ular sekalipun ular itu boleh membiarkan ada ular mati tanpa dikuburkan. Kalau tercium bau bangkai ular di mana pun, kau harus menguburkannya. Tuhan akan menunjukkan beda bangkai ular dengan bangkai lain, seperti kodok. Juga Tuhan akan menunjukkan tempatnya. Lebih dari segalanya, kau harus memperlakukan ular dengan sayang. Ketahuilah, ular itu saudaramu juga. Selanjutnya kau jangan sampai menyakiti hati ular. (Kuntowijoyo, 2013:21-22).

Pertemuan Abu dengan seorang misterius tersebut menjadi ciri khas dari Islam kejawen yang masih memercayai makhluk halus dan kesakten berupa mantra yang dianggap sebagai mitos bagi masyarakat Jawa. Sebagai orang yang beragam Islam, peristiwa yang diceritakan oleh kakek misterius kepada Abu mengenai kanjeng Nabi Nuh, mengisyaratkan pada pesan terkait mantra yang harus diingat dan dihafal oleh Abu dalam melindungi ular. Dari tangan kakek, si Abu merasa sudah menguasai mantra ular, sehingga di manapun ada ular, Abu telah mampu menjinakkan ular.

"Mengapa kau datang menonton, pertunjukan itu untuk bangsa manusia. Tidak untuk bangsa ular," katanya."

Ia sendiri heran, ternyata ia telah berbicara dengan ular itu. Abu membuka tangannya, melepas ular itu. Sebentar ular berhenti. Abu mengerti itu artinya ucapan terima kasih, kemudian menghilang di semak-semak. Ia berdiri, baru menyadari sepenuhnya apa yang telah terjadi dan ia tersenyum. Ia telah menguasai ilmu pejinak ular. Hore! (Kuntowijoyo, 2013:27-28). 
Kebahagiaan tersendiri bagi Abu dalam menguasai mantra yang diajarkan oleh kakek misterius dalam menjinakkan ular, sehingga ini terkategori sebagai sebuah sistem keyakinan terhadap roh halus dan binatang yang mampu mengerti bahasa manusia. Kakek sebagai makhluk halus yang tak jelas asal muasalnya, tiba-tiba mendekati Abu dan mengajarakan ilmu mantra pejinak ular kepada Abu.

Orang itu tertawa panjang, lega. Kemudian menghilang dalam gelap. Abu masih tertegun, merenungkan kejadian yang dialaminya. Disekanya matanya. Tidak, itu bukan mimpi bikan sulapan. Kenyataan itu dialaminya dengan badan wadhag, pasti sungguh-sungguh terjadi. Buktinya, ia ingat dengan jelas mantra yang harus diucapkan. Badannya basah, berkeringat dingin. (Kuntowijoyo, 2013:22).

Gambaran mengenai orang yang mengajar mantra kepada Abu, sebagai isyarat bahwa ada makhluk halus yang dipercayai oleh Abu dalam memberikan ilmu gaib kepadanya mengenai mantra yang harus dikuasai, sehingga syaratnya Abu tidak akan mati, sebelum mewarisi ilmu tersebut. Mantra merupakan perkataan atau ucapan yang dapat mendatangkan daya gaib atau susunan kata berunsur puisi yang dianggap mengandung kekuatan gaib dan biasanya diucapkan oleh dukun atau pawang untuk menandingi kekuatan gaib yang lain (Saputra, 2007: 95-96). Mantra yang dimiliki oleh Abu Kasan adalah kekuatan gaib dalam menjinakan ular sehingga hal tersebut menjadi mitos, bagi masyarakat Jawa khususnya yang menganut Islam kejawen yang masih percaya terhadap kekuatan gaib. Kesaktian mantra yang dikuasai Abu membuat ia terkenal menjadi dukun ular yang dapat menjinakan ular.

Maka ketika Lastri mengatakan bahwa Abu mendapat julukan baru di pasar, Abu menjadi kecut.

"Sampeyan makin terkenal lho di pasar?"

"Hh?"

"Jangan terkejut kalau sampeyan terkenal sebagai Si Dukun Ular." (Kuntowijoyo, 2013:123).

Istilah Dukun Ular ini dilekatkan masyarakat kepada Abu karena kesaktian dalam melindungi diri dan orang lain dari gigitan ular yang sangat berbahaya, sehingga dengan kesaktian itu Abu merasa telah terlindungi dari bahaya ular. Bentuk kepercayaan terhadap mantra ini menjadi sistem keyakinan tersendiri bagi Abu yang merepresentasikan pada keyakinan masyarakat Jawa terhadap kesakten atau kekuatan gaib yang dapat melindungi diri dari bahaya yang menimpa diri. Kesaktian Abu dalam menjinakan ular melalui mantranya tampak pada data berikut.

"Jangan khawatir. Ular saya jinak, kok. Ingin bukti?"

Abu menuju kandang dan membuka tutupnya. Lalu dia bersiul-siul, menunjuk ke dipan. Ular itu menari-nari di sana.

"Jinak, bukan Pak?"

Pak Bayan berdiri. Mulutnya menganga. Tangannya bergerak-gerak, seperti menolak. Mundur-mundur pintu.

"Sudah-sudah." Ia lalu pergi begitu saja. 
Abu merasa sesuatu tak beres. Ada firasat buruk. Bahkan Pak Bayan ketakutan dengan ularnya. (Kuntowijoyo, 2013:180).

Data tersebut menunjukkan keprihatinan kepala dusun yakni Pak Bayan terhadap keresahan dan ketakutan masyarakat terhadap ular peliharaan Abu. Keprihatinan itu ditunjukkan melalui permohonan terhadap Abu agar ular itu diusir dari tempatnya karena meresahkan masyarakat. Ular ini pula yang menjadi penyebab masyarakat membenci Abu. Kebencian masyarakat terhadap Abu menjadi indikasi dari akibat kesaktian yang dimiliki oleh Abu. Pikiran dan ketenangan Abu Kasan Sapari menjadi terganggu karena harus memenuhi pantangan yang harus dilakukan ketika menguasai mantra tersebut. Pantangan berupa meneruskan mantra ini kepada yang lainnya sebelum Abu mati. Kesaktian ini memang mendatangkan keamanan dari gangguan ular, namun juga membuat Abu menjadi menderita karena kebencian dari warga sekitar serta syarat yang harus dipenuhi ketika sudah menguasai mantra pejinak ular yang dianggap sebagai bentuk kesakten bagi masyarakat Jawa.

Kedatangan Abu Kasan Sapari telah ditunggu di kantor kelurahan. Dia dilaporkan bahwa telah membuat takut dan resah dengan memelihara ular. Bahkan orang banyak berkesimpulan bahwa kedatangan Abulah penyebab dari banyaknya ular. Seekor ular muncul di kebunketela, seekor lagi di sumur umum dekat pasar, seekor lagi di dekat beringin. Kabarnya, malah seekor ular jadi-jadian telah menghuni pohon itu. (Kuntowijoyo, 2013:146).

Narasi tersebut menampilkan keresahan masyarakat terhadap binatang peliharaan Abu sehingga keyakinan masyarakat terhadap ular jadi-jadian pun menjadi prasangka masyarakat. Hal tersebut menjadi bentuk sistem religi berupa keyakinan terhadap makhluk halus yang membuat ketakutan masyarakat terhadap kehadiran Abu yang terkenal sebagai dukun ular. Keyakinan terhadap Mantra ini, merupakan bentuk kesyirikan dalam ajaran Islam, sehingga sebagai pengarang sastra profetik, Kuntowijoyo memasukan sistem religi Islam dalam karyanya melalui novel Mantra Pejinak Ular, yakni dengan meninggalkan kepercayaan terhadap mitos berupa mantra yang mendatangkan kesaktian sekalipun malapetaka bagi yang meyakininya. Gagasan religi Islam ini ditampilkan melalui tokoh utama Abu Kasan Sapari yang memiliki nama yang bercirikhas Islam, namun masih percaya kepada kekuatan gaib berupa mantra sehingga Kunto menampilkan perubahan keyakinan Abu terhadap mantra melalui tokoh Haji Syamsudin.

Ketika bertemu Haji Syamsuddin dikatakannya bahwa seusai salat dia ingin bicara. Selesai salat, kata Haji Syamsuddin:

"Wah, ada apa?"

"Begini, Pak. Saya akan melaksanakan anjuran mengenai Ma'ul Hayat itu. Tapi ada halangan."

"Halangan? Laki-laki harus berani, rawe-rawe rantas, malang-malang putung."

"Bukan itu, Pak. Lastri minta say menyingkirkan ular." 


\begin{abstract}
"Apa susahnya? Bawa saja ular itu ke kebun binatang."
"Ular mudah, Pak. Tapi saya terikat dengan mantranya."

"Mantra?"

"Ya Pak. Saya harus mencari orang yang mau ditulari mantra. Mantra harus diturunkan, berkelanjutan sampai kiamat tiba. Kalau tidak saya kena bebendu (malapetaka), tidak akan mati-mati meski tua-renta." "Jangan percaya! Itu gombal, itu sampah. Kau orang beriman.

Karenanya malahan kau wajib memutuskan mata rantai syirik itu.

Sekarang zaman modern, bukan zamannya mantra lagi." (Kuntowijoyo,
\end{abstract} 2013:258-259)

Dialog tersebut sebagai pesan dari Kuntowjioyo untuk melepaskan diri dari keyakinan terhadap mantra yang merupakan perbuatan syirik dalam ajaran Islam. Sebagai orang yang beriman, Haji Syamsudin meyakinkan kepada Abu agar menjauhi dirinya dari bentuk kemusyrikan dengan meyakini mantra tersebut. Sikap Haji Syamsudin dapat diinterpretasikan mewakili golongan Islam santri yang menjauhkan diri dari bentuk kesyirikan sehingga menasehati Abu agar terlepas dari mata rantai kesyirikan. Berdasarkan nasehat dari Haji Syamsudin, $\mathrm{Abu}$ semakin yakni untuk melepaskan mata rantai mantra yang hanya menyusahkan diri sendiri dan orang lain.

Pada waktu itu terdengar azan Subuh. Abu mendengar suara di samping. Itu Lastri. Ia mengerjakan rencananya. Sembahyang dan memasukan ular ke dalam kotak kayu. Ternyata mantranya bikin susah orang lain dan dirinya sendiri! Ia bermaksud memutus mata-rantai mantra itu, tidak mengajarkan mantra pada siapa pun. Kalau ada sangsinya, dia sanggup menanggung. (Kuntowijoyo, 2013:270)

Keyakinan untuk melepaskan diri dari ikatan mantra semakin memperjelas bahwa novel ini merupakan gagasan sastra profetik yang bernuansa sistem religi Islam dengan meyakini ajaran Islam tanpa adanya bentuk kesyirikan.

Selain kepercayaan terhadap mantra, masyarakat Jawa terutama Islam kejawen masih percaya kepada lelembut atau makhlus halus yang berada di sekitar mereka.

Eyang sadar, ia berhadapan dengan makhluk halus. Ia bilang pada pada orang-orang, "Jangan khawatir! Ini mesti ulah Raja Gaple.

"Raja Gaple adalah sebutan untuk kepala lelembut yang tinggal di pekuburan desa. Disebut "Gaple" karena konon hobinya ialah judi. Orang yang malam-malam lewat dekat kuburan desa sering melihat dia sedang berjudi dengan teman-temannya. Eyang menghunus pedang wasiat, lalu malam-malam pergi ke kuburan. Tentu ia juga punya senjata batin. (Kuntowijoyo, 2013:198).

Mereka mengerumuni pohon yang tergeletak di tanah. Mereka tertegun. Ada ketakutan di wajah mereka. Pohon tua, yang entah kapan menenamnya. Pohon yang sudah menyatu dengan Tegalpandan, Waktu mereka kawin meskipun sedikit harus mengambil hiasan daun-daunan 
berasal dari pohon itu. Orang-orang tua masih membakar kemenyan di bawahnya. Pagi itu ada aturan baru untuk bis. Orang-orang pasar juga memerlukan menengok beringin itu sebelum memasang dagangan.

Dalam penebangan pohon yang dianggap sebagai keramat dan berpenghuni itu akan dilakukan selamatan, namun mendapat penolakan dari aktivis Muhammadiyah. Bagi dia, pohon tumbang itu karena sudah wajar melalui akar serabutnya yang tidak kuat lagi menyangga. Bagi lurah, ia khawatir dengan gangguan jin kepada warga akibat tumbangnya pohon beringin yang dianggap warga berpenghuni makhluk halus. Masyarakat banyak yang mengeluh tentang keanehan yang dialami akibat beringin yang tumbang sehingga selalu diganggu oleh jin. Berdasarkan saran dari dukun yang menghadap pada lurah, akhirnya doa selamatan dilaksanakan oleh lurah dengan mengundang Abu Kasan Sapari untuk mendalang dalam selamatan desa. Namun, tak semudah itu Abu memenuhi permintaan lurah, ia teringat pada Eyangnya yang telah menebang pohon keramat tanpa upacara. Ia tidak mau terjadi kemunduran dalam keyakinannya, hanya karena makhluk halus. Ia tetap memenuhi permintaan lurah, tapi diubah dengan cara yang dianjurkan dalam Islam. Berdoa, ceramah, tanpa ada sesajian karena hal tersebut dianggap mengundang syetan. Hal itu berkat nasehat dari Lastri. Kata Selamatan diubah menjadi ruwat bumi atau istilah lain yang tidak mengundang kesyirikan dan juga tidak memakai sesajian. Sistem ritus dan upacara itu melaksanakan dan melambangkan konsep-konsep yang terkandung dalam sistem keyakinan sistem upacara merupakan wujud kelakuan dari religi. Seluruh sistem upacara itu terdiri dari aneka macam upacara yang bersifat harian, musiman atau kadangkala upacara itu masing-masing terdiri dari kombinasi dari berbagai macam unsur upacara, seperti misalnya: berdo'a, bersujud, bersaji, berkorban,makan bersama, menari dan menyanyi (Koentjaraningrat, 2004: 147). Dalam novel ini digambarkan berbagai ritual upacara dengan sesajen akibat tumbangnya pohon yang dianggap keramat oleh masyarakat, diarahkan oleh Kunto kepada pemikiran religi Islam murni tanpa mencampuradukan Islam dengan mitos.

Abu Kasan Sapari berjalan hilir-mudik di rumah. Ia pusing, secara resmi Lurah memintanya untuk mendalang dalam selamatan desa. Ia ingat, Eyangnya saja telah menebang pohon-pohon keramat tanpa upacara. Sekian ratus kemudian cucunya akan mendalang untuk selamatan karena pohon tumbang. "Ini benarbenar kemunduran," pokirnya. Kepada Lurah dikatakannya bahwa dia minta waktu, soalnya rapat LKMD menolak selamatan. Akan dicobanya minta pendapatb Lastri.

"Midah saja. Jangan sebut selamatan." kata Lastri.

"Lalu?"

"Ruwat Bumi, atau apa begitu."

"Undang seorang ustadz untuk berceramah sebelum wayang dimulai."

"Lalu?"

"Jangan pakai sesaji. Kata orang, itu malah mengundang setan," (Kuntowijoyo, 2013:217-218). 
Data tersebut menampilkan bahwa keyakinan terhadap makhluk halus menjadi kebiasaan bagi masyarakat Jawa, sehingga sebagai pengarang yang berlatar belakang Islam memberi pesan bahwa keyakinan terhadap makhluk halus, pohon keramat, lelembut, dan sesajen perlu dihapus karena hanya merusak aqidah sehingga masyarakat diarahkan untuk kembali kepada ajaran Islam yang benar tanpa ada bentuk kesyirikan di dalamnya. Gagasan Profetik Kuntowijoyo tampak melalui perubahan masyarakat Jawa-Islam Kejawen yang masih memiliki tradisi Jawa-Islam yang berbau mistik kepada pemikiran Islam yang berdasarkan Al Quran sebagai sumber utama. Tokoh Abu Kasan sebagai simbol masyarakat Jawa yang masih percaya pada kekuatan gaib, pada akhirnya melepaskan dan memutuskan mata rantai mantra untuk kembali ke era modern dengan tidak terikat dengan hal-hal yang berbau mistik menuju kepada budaya yang masuk akal melalui mengubah acara selamatan yang menggunakan sesajian dengan ceramah agama dan ruwat bumi. Hal tersebut bertujuan untuk menjauhi masyarakat dari kesyirikan.

Tokoh utama yakni Abu Kasan Sapari dilahirkan dan dibesarkan di lingkungan yang masih memegang tradisi Jawa-Islam yang disebut sebegai Islam Kejawen. Hal tersebut tampak pada berbagai upacara sewaku dilahirkan dengan mengunjungi ke makam leluhur Ronggowarsito dalam memperoleh berkah, upacara selamatan, dan berbagai tradisi Islam-Jawa sehingga Abu bertemu dengan makhlus halus yang mengajarkan mantra pejinak ular sebagai kesakten atau kekuatan gaib yang harus dimiliki oleh Abu dengan berbagai pantangan yang harus dilakukan yakni berpuasa, tidak makan garam, dan tidak akan mati sebelum mewarisi ilmu mantra kepada yang lainnya. Kesakten ini sudah mengakar pada tradisi Islam Jawa, sehingga Kuntowijoyo sebagai penulis yang berlatarbelakang budaya Jawa memasukan warna Islam dalam karya-karyanya khususnya dalam novel Mantra Pejinak Ular sebagai bentuk pencerahan bagi masyarakat Jawa dalam menghindari diri dari kepercayaan terhadap mitos dengan hanya percaya pada ajaran Islam yang murni dengan mengandalkan kepada Tuhan sebagai penguasa dan pelindung alam semesta dan menjadikan Al Quran sebagai pedoman. Hal tersebut sebagaimna yang diyakini bagi masyarakat Jawa Islam Santri yakni penganut agama Islam di Jawa yang secara patuh dan teratur menjalankan ajaran-ajaran Islam. Tokoh Abu Kasan Sapari menampilkan sosok manusia Jawa yang menganut Islam Kejawen, bertemu dengan Haji Syamsudin sebagai penganut Islam Santri, sehingga mengubah pola pikir Abu Kasan Sapari dari keyakinan terhadap mantra untuk kembali kepada keyakinan ajaran Islam murni, ssehingga tampak bahwa sistem religi masyarakat Jawa dalam novel Mantra Pejinak Ular merepresentasikan kepercayaan masyarakat Jawa yang terkenal dengan sebutan Islam kejawen dan Islam Santri.

\section{PENUTUP}

Novel Mantra Pejinak Ular karya Kuntowijoyo merepresentasikan sistem religi melalui ajaran agama Islam yang terpengaruh dengan tradisi kebudayaan Jawa yang disebut sebagai Islam kejawen. Ajaran Islam kejawen dalam novel ini tergambar melalui kepercayaan kepada makam leluhur, makhluk halus, mitos, kesakten berupa mantra pejinak ular, upacara selamatan, percaya kepada dedemit, 
pohon keramat, sehingga Kuntowijoyo sebagai pengarang sastra profetik menggagas ide profetik dengan memasukan Islam santri melalui tokoh Haji Syamsudin dengan memberi nasehat kepada Abu agar melepaskan diri dari mata rantai kesyirikan dengan tidak meneruskan mata rantai mantra tersebut kepada orang lain. Namun, Abu sebagai keturunan Islam kejawen dari golongan priyai, ia tetap meneruskan tradisi pewayangan untuk tetap menjadi dalang sebagai sumber spritualitas dalam menghibur sekaligus mengajarkan kebijaksanaan hidup sebagai bagian dari sistem religius Islam kejawen yang harus dipertahankan.

\section{REFERENSI}

Abrams, M. H. (1971). A glossary of literary terms. New York: Holt, Rinehart, Inc.

Anwar, Moh. Wan. 2005. Kuntowijoyo: Menjejak Bumi Menjangkau Langit. dalam Majalah Horison edisi XXXIX/5/2005.

Endraswara, Suwardi. (2008). Metodologi Penelitian Sastra.Yogyakarta: MedPress.

.(2015). Metodologi Penelitian Antropologi Sastra. Yogyakarta:

Ombak.

Herusatoto, Budiono. 2000. Simbolisme dalam Budaya Jawa. Yogyakarta: Hanindita Graha Widia.

Koentjaraningrat. (2000). Pengantar Ilmu Antropologi. Jakarta: Radar Jaya Offset.

. (2002). Pengantar Ilmu Antropologi. Jakarta: Rineka Cipta.

. (1994). Kebudayaan Jawa. Jakarta: Balai Pustaka.

. (2004). Kebudayaan Mentalitas dan Pembangunan. Jakarta: PT

Gramedia Pustaka Utama.

Kodiran. (2010). Kebudayaan Jawa. Jakarta: Djambatan.

Kuntowijoyo.(2013). Mantra Pejinak Ular. Jakarta: PT Kompas Media Nusantara.

Masroer. (2015). Spiritualitas Islam dalam Budaya Wayang Kulit Masyarakat Jawa dan Sunda. Jurnal Ilmiah Sosiologi Agama Volume 9, No. 1, Januari-Juni 2015, hal. 38-61.

Ratna, Nyoman Kutha. (2007). Teori, Metode, dan Teknik Penelitian Sastra. Yogyakarta: Pustaka Pelajar.

(2011). Antropologi Sastra: Peranan Unsur-unsur Kebudayaan dalam Proses Kreatif. Yogyakarta: Pustaka Pelajar.

Santosa, Iman Budhi. 2012. Spiritualisme Jawa. Yogyakarta: Memayu Publishing

Saputra, Heru S.P. 2007. Memuja Mantra, Sabuk Mangir dan Jaran Goyang

Masyarakat Suku Using Banyuwangi. Yogyakarta: LKIS.

Sudikan, Setya Yuwana. (2007). Antropologi Sastra. Surabaya: Unesa University Press.

Oka Rusmini.

Yohanes, Sehandi. 2015. Sastra Indonesia Warna Daerah Provinsi Nusa Tenggara

Timur dalam Prosiding Sastra Kita: Kini, Dulu, dan Nanti.

Bandung: Unpad Press. 